\title{
Effect of food preservative and food coloring agent on some physiological and hematological parameters in albino rats and the protective role of garlic
}

\author{
Eman G.E. Helal* and Mervat Abdel- Rahman** \\ *- Zoology Department, Faculty of Science, Al- Azhar University (Girls). \\ **. Clinical Pathology Lab., Student Hospital, Cairo University.
}

\begin{abstract}
:
Most children, in the age of nursery consume food that contains both colorants and preservatives with great amount. This observation led us to study the interaction between sodium nitrite as a food preservative and sun set yellow as a coloring agent. The mixture of the two agents at the limited dose of each was found to be a lethal dose. So, $1 / 10^{\text {th }}$ of this dose was used daily for 30 days. Animals were divided into three groups. The first group served as a control, while the second group was orally administered a mixture of $10 \mathrm{mg}$ sod.nitrite $(\mathrm{NaNO} 3) / \mathrm{kg}$ mixed with $0.5 \mathrm{mg} / \mathrm{kg} /$ day sun set yellow (S.S.Y). The third group received garlic $(5 \mathrm{mcg} / \mathrm{kg})$ in addition to the above mentioned mixture. After 30 days of treatment, half of the animals from each group were decapitated. The other half of the animals was left for another 15 days without any additional treatment as a recovery period.

Ingestion of the mixture of (NaNO3 and S.S.Y) significantly decreased rat body weight, RBCs and WBCs counts, $\mathrm{Hb} \%$, Hct\%. No changes were recorded for organ/ body weight, respiratory rate, heart rate, rectal temperature.

A complete recovery from the abnormalities of most physiological and hematological parameters was observed after the recovery period or when garlic was administered.
\end{abstract}

Key Words: Garlic, antioxidant, preservatives, colorants.

\section{Introduction:}

Food additives are substances internationally added to food. They may be natural or synthetic (Harris, 1986). The principal classes of food additives are coloring agents, preservatives, flavors, emulsifiers and stabilizers (Lindsay, 1985). Common anti-microbial preservatives include sodium nitrate, sodium nitrite, sulpher dioxide, sodium bisulphate, potassium bisulphate, ect and disodium EDTA.

One of the principal preservatives are the nitrites which are used in the form of salts or free acids (HMSO, 1987). The use of sodium nitrate as a preservative is common in cooked meat, sausages and the milk used for some types of cheese. Because of the use of more than one type of such food, the percentage of nitrite content of the daily food ratio may be higher than the admissible level (Bilczuk et al., 1991). Apparently very little nitrites are formed by endogenous synthesis and most, if not all, are of dietary origin (Bartholomew and Hill, 1984).

Food colorants may often be considered simply cosmetic in nature, but its role is very significant. Both food quality and flavor are closely associated with color. Consumers are conditioned to expect food of certain colors and to reject any deviation from their expectations (Amerine et al.,1965).

Every food designer knows that consumers judge a product not only on its 
flavor, but on its appearance as well. One important class of ingredients exists solely to enhance the appearance of what we eat: food colors. In recent years, product designers have been asked to formulate using so-called natural colors with increasing frequency. This presents a set of challenges that is totally different to those presented when using certified colors. (Kuntz, 1994).

Garlic has played an important dietary and medical role through the history of mankind. In some western countries, the sale of garlic preparations ranks with those of leading prescription drugs. The therapeutic efficacy of garlic encompasses a wide variety of ailments, including cardiovascular, cancer, hepatic microbial infections. Various preparations of garlic, mainly aged garlic extract (AGE), have been shown to have promising antioxidant potential. However, the presence of more than one compounds in garlic, with apparently opposite biological effects, has added to the complexity of the subject. Raw garlic homogenate has been reported to exert antioxidant potential but higher doses have been shown to be toxic to the heart, liver and kidney (Banerjee et al., 2003).

It has been noticed that children often eat food containing preservatives and at the same time drink some drinks containing colorants. The question arises here whether food preservatives and colorants would interact with each other. The aim of this work is therefore to test this possibility by mixing a limited dose of sodium nitrite (one of the most used preservatives) with a limited dose of sunset yellow (one of the most attractive colorants (and test their recombinant effect on rats). The interaction of both limited doses resulted in a recombinant lethal dose that led to the death of all rats used. So, this study was planned to achieve two goals: The first is; to follow up the biological effect of this mixture on young male albino rats: and the second; is to study the effect of garlic (one of the most potent antioxidant) in order to illustrate the possibility of ameliorating the expected hazards.

\section{Material and method:}

Thirty young male albino rats (weighing about 70-80 gm) were used in this study. Animals were housed in stainless steel cages, fed on rat chew and offered water ad libitum. The animals were divided into three equal groups (10 rats each) as follows:

The first group: (control group)

The second group: Orally administered $10 \mathrm{mg} \mathrm{Na} \mathrm{No3/Kg}$ and $0.5 \mathrm{mg}$ sun set yellow (S.S.Y.) daily for a month.

The third group: Received the same dose of Na No3 and S.S.Y in addition to 50 $\mathrm{mcg} / \mathrm{Kg} / \mathrm{day}$ of garlic administered by oral intubation to each rat, for one month.

Body weights, respiratory rate, heart rate and rectal temperature were recorded once a week throughout the experimental period. After 30 days of treatment, 5 animals of each group were weighed and then decapitated. While the other half was kept for two weeks without any additional treatment for recovery.

From each of the decapitated rats, liver, kidney, hearts and testes were dissected out, cleaned from adherent tissues and weighed at once.

Blood samples were collected and EDTA, an anticoagulant, was added to the collected blood for hematological parameters. Hemoglobin concentration was determined according to Van-Kampen and Zulstra (1961). Red and white blood cells were counted, and haematocrit values (Hct) were estimated using the technique of Rodak (1995).

Student t-test was used for comparison of data obtained for different parameters from different experimental animal groups. Significant differences between the means of control and treated groups were considered only at $(\mathrm{p}<0.05)$ (Sokal and Rohif, 1981).

\section{Results:}

Control young rats showed a net gain (19.6\% and $18.9 \%)$ in body weight after the treatment and recovery periods respectively; while the gain of body weight in rats treated 
by the mixture of sodium nitrite, sunset yellow (NaNO3 and SSY) and garlic signify-cantly was higher $(22.5 \%$ and $18.9 \%)$ as compared to control $(\mathrm{p}<0.01)$. On the other hand, there was significant $(\mathrm{p}<.01)$ weight loss in rats treated with a mixture (NaNO3 and SSY). After recovery period (15 days), there was a gain in the body weight (10.6\%) table (1). The organs/body weight of male albino rats treated and control rats after both treated and recovery periods are presented in table (1). No significant detectable changes in the relative weight of the kidney, brain, heart, liver and testes were recorded in all treated groups.

All of the animals showed nansignificant changes in respiratory rates, heart rate and rectal temperature, after both treated and recovery periods (Table 2 ).

Investigation of the effect of oral administration of the mixture of sod.nitrite and sunset yellow on red blood cells, hemoglobin, haematocreite, revealed highly signi-fycant decrease $(\mathrm{P}<.01)$ in all parameters. Supplementation with garlic, however resulted in values for hematological parameters which was Nan significantly recorded from control rats . After the recovery period, no signifycant values were recorded in all treated groups as shown in figures (1-4). Teatment with the mixture caused significant reduction in white blood cell count as shown in figure (1).

Table (1): The change in body weight gain and in the ratio of organ weight/body, weight of rats control, rats (control, treated with NaNO3+SSY and treated with $\mathrm{NaNO} 3+\mathrm{SSY}+\mathrm{garlic})$ after experimental and recovery periods.

\begin{tabular}{|c|c|c|c|c|c|c|c|}
\hline \multirow[t]{2}{*}{ Parameter } & & \multicolumn{3}{|c|}{ Treated period } & \multicolumn{3}{|c|}{ Recovery period } \\
\hline & & Control & $\mathrm{NaNO}+\mathrm{SSY}$ & $\begin{array}{c}\text { NaNO+SSY } \\
\text { +Garlic }\end{array}$ & Control & NaNO+SSY & $\begin{array}{c}\text { NaNO+SSY } \\
\text { +Garlic }\end{array}$ \\
\hline \multirow{3}{*}{$\begin{array}{l}\text { \%of body } \\
\text { weight }\end{array}$} & $\mathrm{X}$ & 19.6 & 11.9 & 22.5 & 18.94 & 10.6 & 18.9 \\
\hline & S.E & 0.26 & 0.69 & 2.2 & 0.4 & 0.4 & 0.5 \\
\hline & $\mathrm{P}$ & & $<.01$ & $<.01$ & & $<.01$ & N.S \\
\hline \multirow{3}{*}{$\begin{array}{l}\text { Kidney/ } \\
\text { b.wt }\end{array}$} & $X$ & 0.7 & 0.5 & 0.5 & 0.6 & 0.5 & 0.56 \\
\hline & S.E & 0.02 & 0.02 & 0.09 & 0.03 & 0.02 & 0.02 \\
\hline & $\mathrm{P}$ & & $<.01$ & N.S & & $<.05$ & N.S \\
\hline \multirow[t]{3}{*}{ Brain b.wt } & $X$ & 0.86 & 0.86 & 0.84 & 0.9 & 0.85 & 0.9 \\
\hline & S.E & 0.03 & 0.03 & 0.05 & 0.02 & 0.04 & 0.02 \\
\hline & $\mathrm{P}$ & & N.S & N.S & & N.S & N.S \\
\hline \multirow{3}{*}{$\begin{array}{l}\text { Cardio- } \\
\text { somatic } \\
\text { index } \\
\end{array}$} & $X$ & 0.6 & 0.4 & 0.58 & 0.62 & 0.45 & 0.56 \\
\hline & S.E & 0.02 & 0.02 & 0.01 & 0.04 & 0.02 & 0.04 \\
\hline & $\mathrm{P}$ & & $<.01$ & N.S & & $<.01$ & N.S \\
\hline \multirow{3}{*}{$\begin{array}{l}\text { Hepato- } \\
\text { somatic } \\
\text { index }\end{array}$} & $X$ & 3.2 & 2.5 & 3 & 3 & 2.9 & 3 \\
\hline & S.E & 0.09 & 0.1 & 0.1 & 0.1 & 0.1 & 0.2 \\
\hline & $\mathrm{P}$ & & $<.01$ & N.S & & N.S & N.S \\
\hline \multirow{3}{*}{$\begin{array}{l}\text { Ganado- } \\
\text { somatic } \\
\text { index }\end{array}$} & $X$ & 1.07 & 0.9 & 0.9 & 1.1 & 0.8 & 1.02 \\
\hline & S.E & 0.02 & 0.05 & 0.04 & 0.02 & 0.05 & 0.04 \\
\hline & $\mathrm{P}$ & & $<.01$ & $<.01$ & & $<.01$ & N.S \\
\hline
\end{tabular}

S.E=avera rage \pm 
Table(2): The effect of sodium nitrite and SSY and garlic on respiratory rate, heart beats and rectal temperature after experimental and recovery periods.

\begin{tabular}{|c|c|c|c|c|c|c|c|}
\hline Parameter & & \multicolumn{2}{|c|}{ Treated period } & \multicolumn{2}{c|}{ Recovery period } \\
\cline { 3 - 8 } & & Control & NaNO+SSY & $\begin{array}{c}\text { NaNO+SSY } \\
\text { +Garlic }\end{array}$ & Control & NaNO+SSY & $\begin{array}{c}\text { NaNO+SSY } \\
\text { +Garlic }\end{array}$ \\
\hline Respirat- & $\mathrm{X}$ & 49 & 51 & 44 & 48.2 & 48.6 & 43.8 \\
ory rate & $\mathrm{S} . \mathrm{E}$ & 1.8 & 0.5 & 0.6 & 1.2 & 0.9 & 0.7 \\
(breath/min) & $\mathrm{P}$ & & $\mathrm{N} . \mathrm{S}$ & $<.05$ & & $\mathrm{~N} . \mathrm{S}$ & $<.05$ \\
\hline Heart & $\mathrm{X}$ & 136 & 139.6 & 134 & 134 & 133.6 & 128 \\
beat/min. & $\mathrm{S} . \mathrm{E}$ & 1.8 & 0.7 & 4.3 & 1.8 & 1.1 & 3.3 \\
& $\mathrm{P}$ & & $\mathrm{N} . \mathrm{S}$ & $\mathrm{N} . \mathrm{S}$ & & $\mathrm{N} . \mathrm{S}$ & $\mathrm{N} . \mathrm{S}$ \\
\hline Rectal & $\mathrm{X}$ & 34.72 & 34.52 & 34.86 & 34.64 & 33.94 & 34.6 \\
temperature & $\mathrm{S} . \mathrm{E}$ & 0.09 & 0.7 & 0.3 & 0.15 & 0.4 & 0.2 \\
C & $\mathrm{P}$ & & $\mathrm{N} . \mathrm{S}$ & $\mathrm{N} . \mathrm{S}$ & & $\mathrm{N} . \mathrm{S}$ & $\mathrm{N} . \mathrm{S}$ \\
\hline
\end{tabular}

Fig.(1): The effect of sodium nitrite, S.S.Y. and garlic on W.B.Cs.

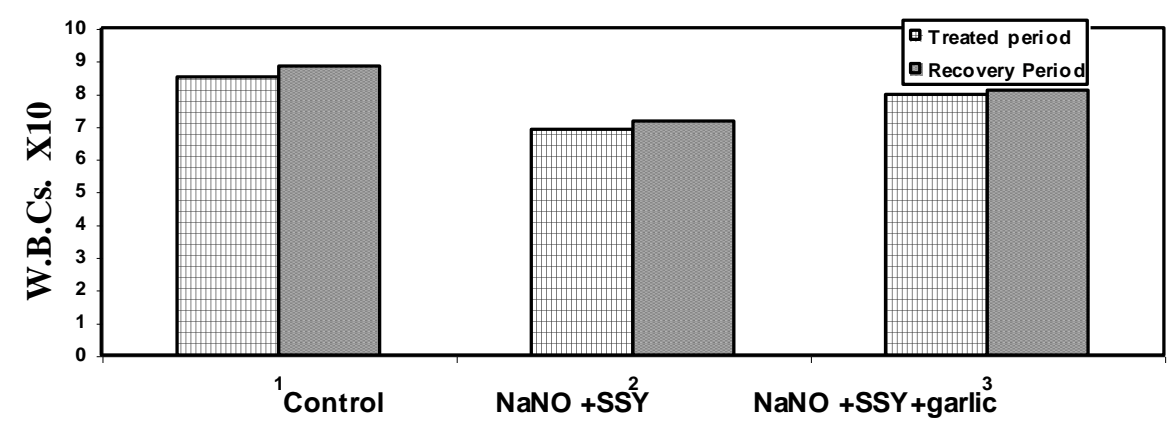

Fig.(2): The effect of sodium nitrite, S.S.Y. and garlic on R.B.Cs.

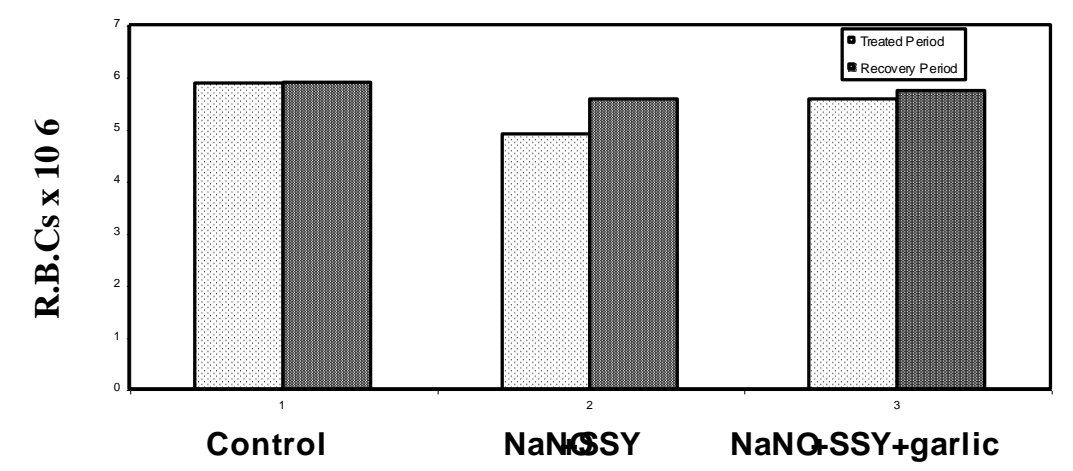


Fig.(3): The effect of sodium nitrite, S.S.Y. and garlic on hemoglobin concentration (HB\%).

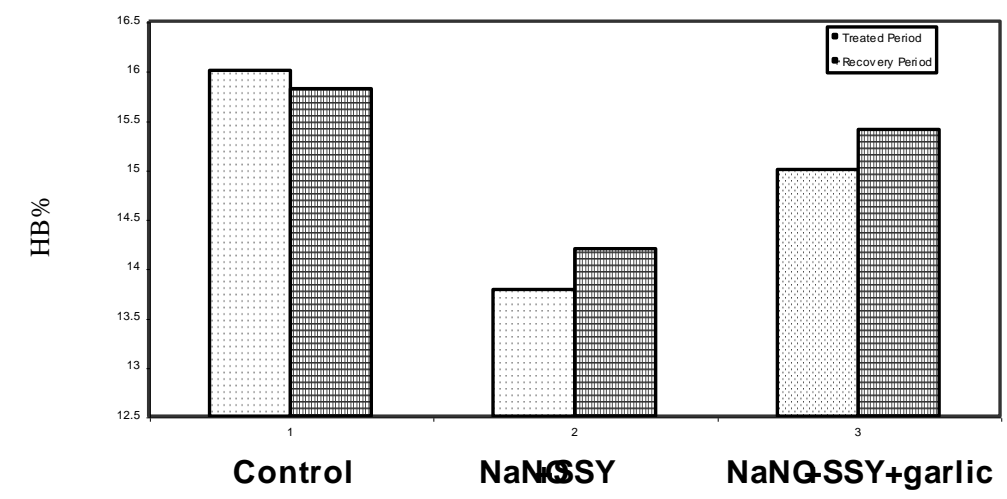

Fig.(4): The effect of sodium nitrite, S.S.Y. and garlic on hematocrit value (Hct\%).

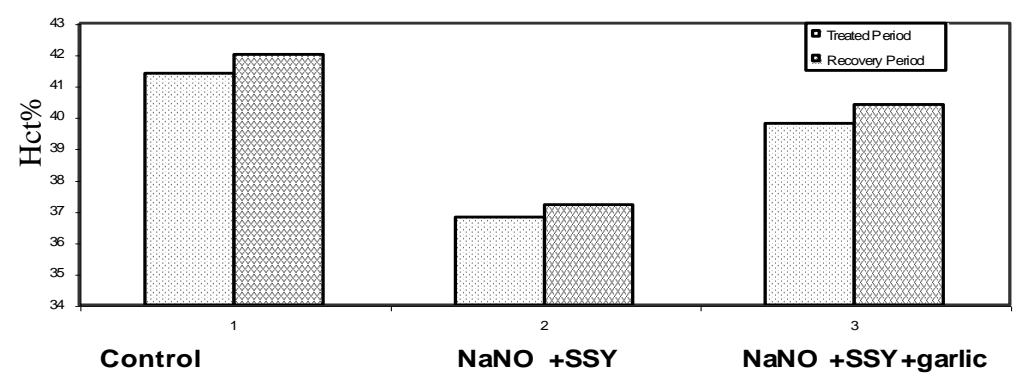

\section{Discussion:}

The present observations of body weight loss after the treatment with both food preservator and food colorant may be due to the reduction of food consumption (Grant and Butler, 1989). On the other hand, the reduction of mean body weight may be due to the increase in the level of both nitrite and sunset yellow leading to increased catabolic processes in the body. Greenblatt and Mirvish (1972), Maekawa et al., (1982) and Til et al.(1998) recorded a reduction of body weight gain due to nitrite treatments. Many investigators recorded a reduction in body weight as a result of colorants supplementation (Brozelleca et al. 1989; Osman et al., 1995 and Abu El-Zahab et al.,1997). In the present measurements, it was found that garlic ameliorates the catabolic effect of both $\mathrm{NaNO} 3$ and S.S.Y.

The present results showed nansignificant changes of the relative weight of the tested organs of the male rats treated with $\mathrm{NaNO} 3+$ SSY or with NaNO3 + SSY + garlic. Hirose et al., (1993) and Yoshidae et al., (1994) renaticed an increase of absolute and relative liver and kidney weights of rats treated with sodium nitrite. These results are in contrary with those of the present work. This could be due to the lesions and other disturbances (Dini et al.,1992, and Hirose et al., 1993) leading to loss of nutrient and fluids or to inhibition of gastrointestinal mucosa $\mathrm{Na}+/ \mathrm{K}+$, ATP ase and alkaline phosphatase (Bruning-Fann and Kaneene,1993).

The present data revealed that respiration rate, heart rate and body temperature are almost the same in all groups under the treatment conditions.

Administration of both sod.nitrite and S.S.Y. for one month to rats induced a decease of W.B.Cs,R.B.Cs, $\mathrm{Hb} \%$ and $\mathrm{Hct} \%$. It is known that 
nitrites convert the ferrous ion of hemoglobin to ferric ion both in vivo and vitro (Ganong, 1997). This can explain the reduction of hemoglobin level. .In other words, administration of both nitrite and SSY leads to haematopoietic tissue hypoxia resulting on the long term (one month in the present study) to a decrease of blood cell production and hence to reduction of blood hemoglobin level .

The decrease of hemoglobin due to nitrite treatment has been reported using different animals including rats (Abdel-Rahim et al.,1988, Smith, 1991 and Reutov et al.,1993), mice (Walker et al.,1957), dogs (Harely and Robin, 1962), swine and sheep (London et al.,1967). Further, nitrites have been reported to induce a reduction of haemoglobin level in human (Heisler et al., 1974 and White, 1975).

The present results are, in part, comparable to those obtained by Rastogi and Prasad (1983 a \& b) where they found that feeding of albino mice in the common food color metanil yellow led to changes in hematological values. Total erythro-cyte count and hemoglobin had decreased. Erthrocyte sedimentation rats (E.S.R.) mean corpuscular volume (MCV) and mean corpuscular hemoglobin concentration (MCHC) had increased. These facts suggested the occurance of normoc-hromic macrocytic anemia.

Differential leukocyte count showed marked increase in the number of lymphocytes and mon-ocytes and decrease in the number of neutrophils and eosinophils (Rastogi and Prasad,1983b). The present study was in accordance with Mackenzie et al., (1992) who found a reduction in total white blood cell counts as a result of caramel treatment in rats. Also it was clear that dual treatment in the present study had ameliorated all hematological variation.

Garlic has been shown to have promising antioxidant potential that defends against free radicals damage, thereby preserving the body's healthy functioning (Hey,2002). So, it's well recommended to use a moderate dose of garlic daily in children and adult's food since it protects them against pro-oxidant and other tragic effects resulting from food additives and other food toxins. Aged garlic Extract (AGE) can protect vascular endothelial cells from oxidant injury. Also garlic contains about $0.5 \%$ of a volatile oil that is composed of sulphercontaining compo-unds. Garlic's sulpher compounds, in addition to selenium and Vitamins $\mathrm{A}$ and $\mathrm{C}$ containing compounds, make it a potent antioxidant, protecting cell membranes and DNA from damage and disease. So, it is important to keep an array of antioxidant compounds to develop good herbal preparation, like AGE (Yamasaki \& Lau, 1997).

\section{References}

1. Abdel-Rahim, E.A.: El-Desoky, G.E: Shaban, O.A and Afify, A.s. (1988): Studies on the effect of sodium nitrite on hemoglobin fractions and growth rate of albino rats. Bull. Fac. of Agric. Univ. of Cairo, 39 (4): 1503-1561.

2. Abou El-Zahab, H.S.H; El-Khyat, Z.A.; Awadallah, R. and Mahy, K.A. (1997): Physiological effects of some synthetic food coloring additives on rats. Boll. Chim. Farm., 136 (10): 615-627.

3. Amerire,M.A.; Pangborn, R.M.; Rossler, E.B. (1965): Principles of Sensory Evaluation of Food. Academic Press, New York.

4. Banerjee S K; Mukherjee P K, Meulik S K. (2003): Effect of garlic and antioxidant supplementation on oxidative DNA damage in lymphocytes of healthy human volunteers. Phytother Res.; 17 (2): 97-106.

5. Bartholomew, B. and Hill, M.J. (1984); The pharmacology of dietary nitrite and the origin of urinary nitrate. Fd. Chem. Toxic., 22: 789 .

6. Bilczuk, L.; Gowin, A.; Ebertowska, Z. and Mach, H. (1991): Nitrate and nitrite levels in daily food rations of children from the rural pulowy regions. Rocz. Panstw. Zaki. Hig. 42 (2): 139-147.

7. Brozelleca, J.F.; Olson, J.W. and Reno, F.E. (1989): Life time toxicity carcinogenicity study of FD \& C Red no. 40 (Allura Red) in Sprague- Dawley rats. Fd. Chem. Toxic., 27 (11): 701-706.

8. Bruning - Fann, C.S. and Kaneene, J.B. (1993): The effect of nitrate, nitrite and $\mathrm{N}-$ nitroso compounds on animal health. Vet. Hum. Toxicol., 35 (3): 237-253.

9. Dini, L., Bernardini, R.; Resti, M. and viercei, A. (1992): Unusual reaction to food additives. Pediatr. Med. Chir., 14 (1): 39-42.

10. Ganong, W.F. (1997): Review of Medical Physiology. $8^{\text {th }}$ ed. Libraure du Liban, Appe-lton of Longe, Lebanon, California, 296-311.

11. Grant, D. and Bulter, W.H. (1989): Chronic toxicity of sodium nitrite in male $\mathrm{F}$ -344 rat. Fd. Chem. Toxic., 27 (9):565-571.

12. Greenblatt, M. and Mirvish, S.S. (1972): Dose - response studies with concurrent 
administration of piperazine and sodium nitrite to strain a mice. J. Nat. Concer. Int., 49: 119-124.

13. Harley, J.D. and Robin, H. (1962): The effect of the nitrite ion on intact human erythrocytes. Blood, 20 (6): 710-713.

14. Harris, J.B. (1986): Natural toxins. Animal, plant and microbial. Cited in: Food and additives in tolerance in childhood (1994). P. 179. Black well scientific London - Boston.

15. Heisler, E.G.; Sciliano, J.; Krulick, S.; Feinberg, J. and Schwartz, J.H. (1974): Changes in nitrate and nitrite content and search for nitrosamines in storage, Abused spinach and beets. J. Agric. Food Chem., 22 (6): 1029-1032.

16. Hey, B. (2002): Aged Garlic: A Potent Antioxidant. Issue of Natural Foods Merchandiser, March 2002.

17. Hirose, M.; Tanaka, H.; Takahashi, S.; Futakuchi, M.; Fukushima, S. and Ito, N. (1993): Effects of sodium nitrite and catechol in a rat multi-organ model. Cancer Res. 53 (1): 32-37.

18. H M S O. (Her majesty's stationary office, London). (1987): Food additives. The balanced approach. Cited in food additives intolerance in childhood (1994) p. 180. Black well scientific. London Boston.

19. Lindsay, R.C (1985): Food additives in fennema. Cited in: Food additives intolerance in childhood. P.179. Ed. David, T.J. Blackwell scientific. London - Boston.

20. London, W.T.; Henderson, W. and Cross, R.F. (1967): An attempt to produce chronic nitrite toxicosis in swine. J.A.V.M.A., 150 (4): 398-402.

21. Mackenzie, K.M, Boysea, B.G, Field, W.E, Petseel, S.A.W; Chapel, C.I, Enerson, J.L AND STAALEY, J (1992): Toxicity studies of caramel color 111 and 2- acetiyl- 4 (5)- tetrahydroxybutylimidzole in F344 rats. Food and chemical toxicology. 30 (5): 417-425.

22. Maekawa, A.; Ogin.; Onodera, H; Furuta, K.; Matsuoka, C.; Ohho, Y. and Odoshima, S. (1982): Carcinogenicity studies of sodium nitrite and sodium nitrate in F-344 rats. Fd. Chem. Toxic., 20: 25-33.

23. Osman, M.A.; Afifi.; A.; Hussien, R.M.; Kamilia, B.; Abdel-Aziz and Salah, S.H. (1995): Long-term biochemical and genotoxicity studies of four synthetic food and drug colorants in mice. Bull. Fac. Pharm. (Cairo Univ.), 33 (1): 13-12.

24. Rastogi, P.B. and Prasad, O.M. (1983a): Hematological changes induced by feeding a common food color metanil yellow in albino mice. Toxicol. Lett., 16: 103- 108.

25. Rastogi, P.B and Prasad, O.M. (1983b): Hematological abnormalities induced by pre-feeding a common food color metanil yellow in mice. Proc. Acad. Sci. India Sec. B., 53 (1): 1-10.

26. Reutov, V.P.; Sorokina, E.G; Pinelis, V.G; Korshunova, T. S.; Rodionov, A.A; Koshelev, V.B; Strukova, S.M; Kaiushin, L.P; Braquet, P. and Komissarova, L.K.H. (1993): The compensatory adaptive mechanisms in nitrite - induced hypoxia in rats. Biull. Eksp. Biol. Med., 116 (11): 506-508.

27. Smith, R.P. (1991): Chemicals reacting with various forms of hemoglobin: biological significance, mechanisms and determination. J. Forensic Sci., 36 (3): 662-672.

28. Sokal, R.R. and Rohif, F.J. (1981): Biometry: The principles and practice of statistics in biological research. $2^{\text {nd }}$ ed. Freeman, W.H. Company San Francisco.

29. Til, P.; Falke, H.E.; Kuper, C.F. and William, M.I. (1998): Evaluation of the oral toxicity of potassium nitrite in a $13-$ week drinking water study in rats. $\mathrm{Fd}$. Chem. Toxic., 26 (10): 851-859.

30. Van Kampen, E.J. \& Zulstra, W.G. (1961): Standerdization of hemoglobinometry: The hemoglobin cyanide method. Clin. Chem. Acta.: 538-540.

31. Walker, B.S; Boyd, W.C. and Asimov, I. (1957): Biochemistry and human metabolism. Williams \& Wilkins - Baltimore, New York.

32. White, J.W. (1975): Relative significance of dietary sources of nitrate and nitrites. J. Agric. Food Chem., 23 (5): 886-891.

33. Yamasaki T. \& Lau B.H. (1997): Garlic compounds protect vascular endothelial cells from oxidant injury. Nippon Yakurigaku Zasshi, 110 Suppl 1: 138-141.

34. Yoshidas, Y.; Hirose, M.; Takaba, K.; Dinura, J. and Ito,N. (1994): Induction and Promotion of forestomach tumors by sodium nitrite in combination with ascorbic acid or sodium ascorbate in rats with or without N-methyl-N-nitro-N-nitrosogunidine pretreat-ment. Int. J. Cancer, 56: 124-128. 


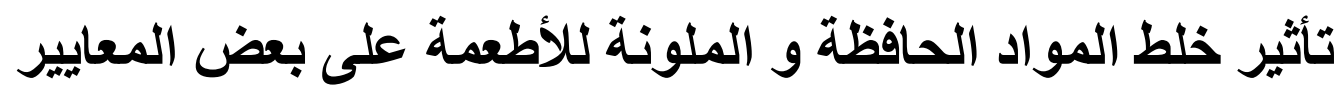

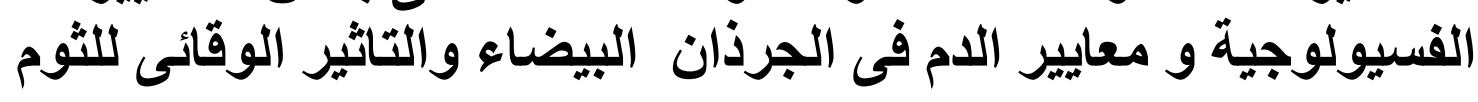

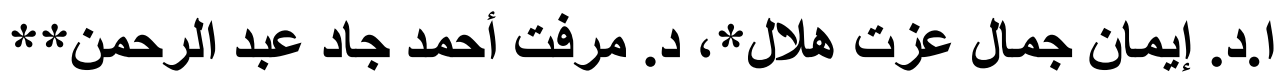

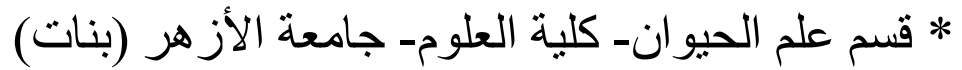

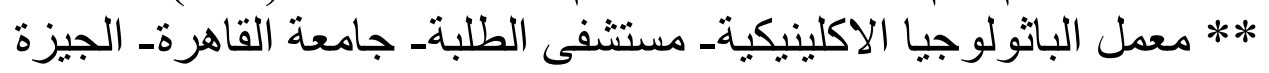

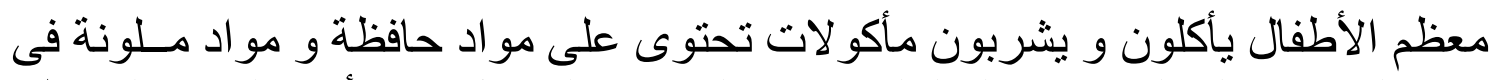

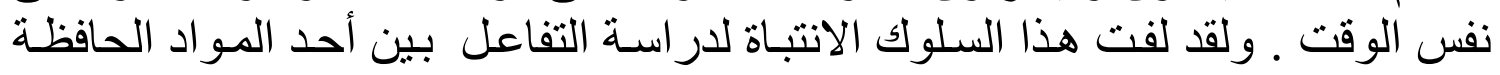

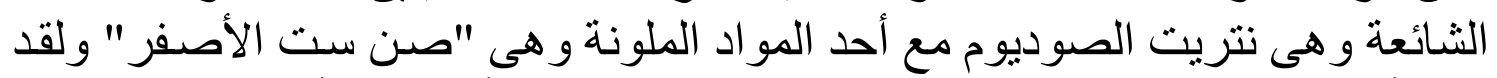

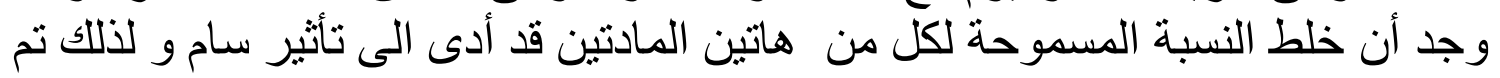

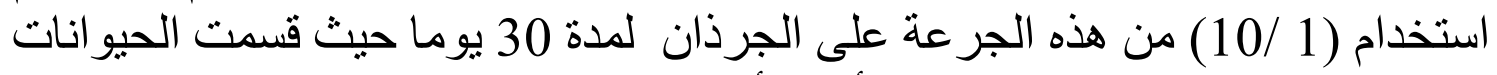

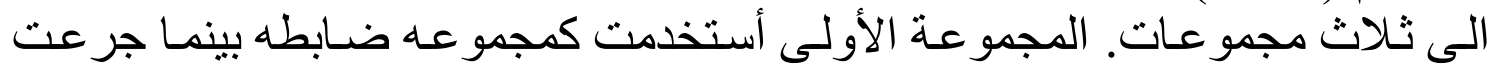

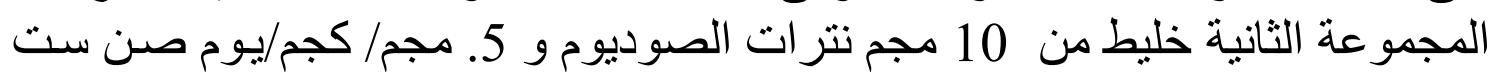

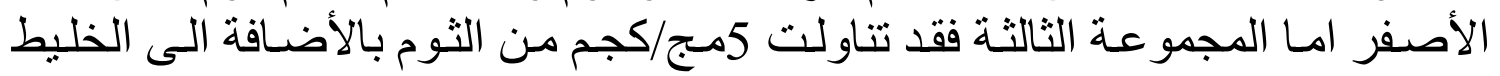

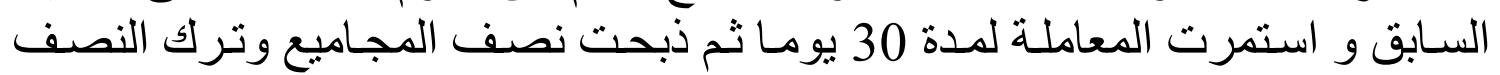

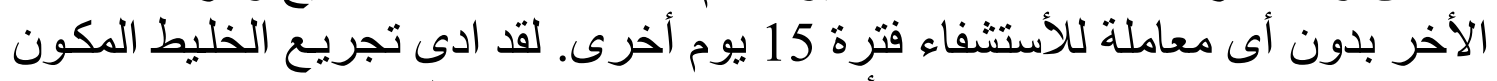

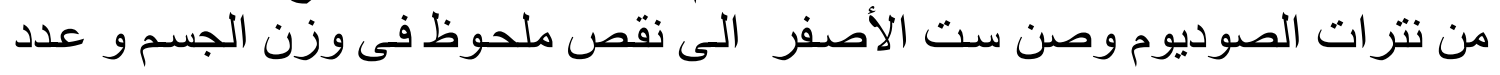

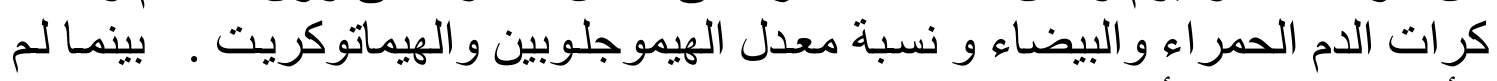

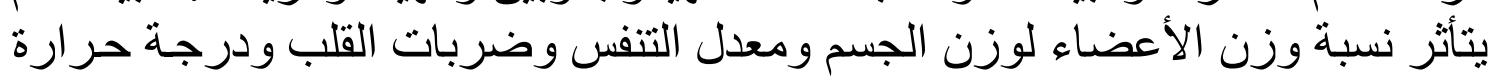
وقد لوحظ أنه قد تم الثفاء من أغلب هذه التغيرات الفسيولوجيه ومعايير الدم ام

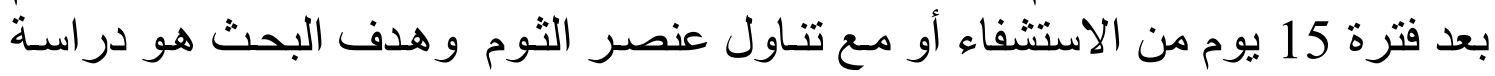

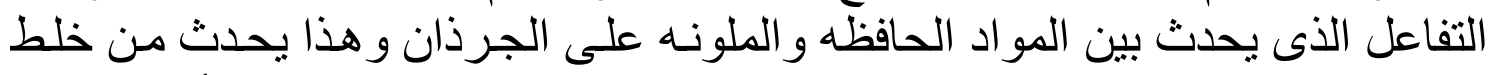

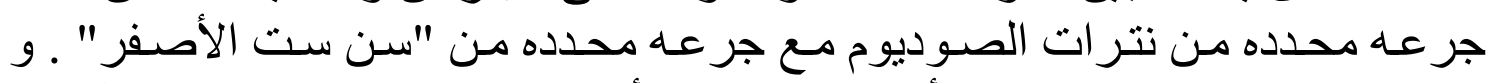

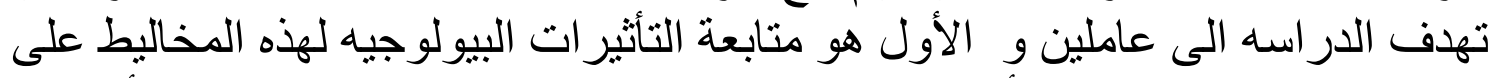

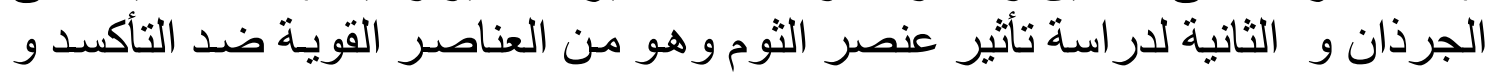

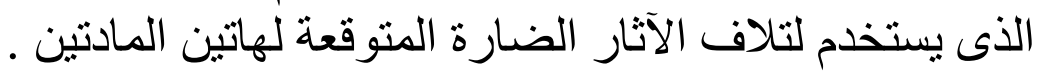

